\title{
Integration of Landed Refugee Claimants in Canada: Toward an Explanatory Model
}

\author{
Edward Opoku-Dapaah
}

This paper seeks to develop a framework for explaining the integration process of landed refugee-claimants in Canada. The main focus is on Third World origin landed claimants who arrived in Canada during the 1980s. The central argument is that the social and economic background of landed refugee-claimants, together with their past and recent experiences, tend to result in their marginalization within the Canadian socioeconomic context. Past experiences of refugee claimants include political violence, physical assault and repression which precipitated their departure abroad. Experiences in Canada, such as delays in the acquisition of legal status, restrictive access to settlement-related services, and racism create anxiety, discouragement and economic dependency. This paper contends that such past experiences can make it difficult for landed refugee-claimants to participate effectively in social and economic activities and subsequently create barriers to integration.

In this paper integration is conceptualized as the ability of immigrants and refugees to settle into the existing Canadian social mosaic, benefitting fully from available opportunities, without emerging as a subclass. This definition is based on the observation that Canada's official multicultural policies promote the pluralistic coexistence of diverse social groups. It is officially assumed that relatively equal opportunities should be available to every Canadian, provided that the person is equipped with the resourcefulness, ability, and ambition to take advantage of such opportunities (Boyd 1987).

Edward Opoku-Dapaah is a doctoral candidate in sociology and a research associate at CRS, York University.

\section{Context}

The 1980s saw an unprecedented number of Third World origin immigrants who travelled to Canada as visitors and then sought refugee status upon arrival. People who press refugee claims from within Canada have been referred to as "inland refugeeclaimants," "asylum seekers," and "spontaneous refugee-applicants." People in these categories will all be referred to as "claimants" in this paper. Claimants whose refugee applications are successful are granted permission to stay permanently in Canada; those who are unsuccessful are made to leave "voluntarily" or face deportation. The term "landed claimants" is used here to designate claimants who have successfully completed the in-Canada refugee application process and have acquired the legal rights to stay permanently. The characteristics of Third World origin landed claimants are discussed below.

\section{Distinctive Origin}

People who sought asylum in Canada throughout the 1980 s came mainly from Sri Lanka, Somalia, China, Poland, Ghana, Iran, Haiti, El Salvador and Portugal. The Third World origin of contemporary refugees is a recent historical development in Canada. Prior to 1968, refugees and immigrants to Canada came mainly from Western Europe or the United States. The immigration policy for that period was based on the assumption that people from certain racial and cultural backgrounds would be unable to participate in Canadian economic, political and social processes (Satzewich 1991). People of non-European backgrounds, such as the Chinese, Japanese and East Indians, were restricted from settling in Canada because they were seen as a threat to Canadian economic stability and cultural identity (Verma and Bun Kwok 1992). Subsequent to 1968 , immigrants and refugees in Canada have come mainly from Eastern Europe and other parts of the world such as South East Asia, West Asia, Latin America, Africa and the Middle East.

\section{Cultural and Social Prejudice}

The distinctive cultural characteristics of landed claimants can give rise to racism and ethnic discrimination. Although publicly admitted prejudice against ethnic minorities in Canada may be declining, privately held prejudice still remains at significant levels (Simmons 1990). Economic and residential indicators suggest that certain visible minorities suffer disproportionately from prejudice, and that their economic success in Canada is proportionately reduced (ibid). Studies have also documented the behaviour of employers and landlords in Toronto toward minority groups such as Chinese, Blacks and South Asians. It was found that a variety of screening processes effectively discriminates against these groups without being overt enough to be detected by the applicant, or to be used as evidence in a tribunal or court (Richmond 1989).

Particularly in the case of claimants, racist sentiments can lead to exaggerated scepticism about the credibility of their refugee applications. This was graphically illustrated in a recent fivepart series on Canada's immigration system in a major newspaper. The series questioned the legitimacy of refugee claims made by Portuguese, Ghanaians and Somalis (Stoffman 1992, A19). Given the media attention, it is not surprising that Canadians are greatly concerned about the possibility that a significant number of inland refugee applicants are actually " queue jumpers," that is, economic opportunists masquerading as refugees in order 
to avoid waiting for admission through regular immigration procedures (Simmons 1990).

Racism can also have a negative impact on the job prospects of landed claimants. In short, the cultural background of landed claimants in Canada places them in the ranks of a disadvantaged minority group. The consequences can include discrimination in the spheres of employment, acquisition of accommodation and in the case of claimants, public scepticism of their claim of refugee status.

\section{Flight-related Trauma}

Landed claimants may have been traumatized by preflight experiences of coercion, torture, rape, starvation and other abuses [see Hutton in this issue]. Such trauma can be aggravated by the stress of flight from their homeland to Canada. For many refugee-applicants, the psychological reaction to the circumstances of exit, and the loss of relatives and material possessions, entail a long process of grief and mourning, heightened anxiety and depression, and an overwhelming sense of helplessness and hopelessness (Rumbaut 1991, 381). Without medical intervention and appropriate resettlement conditions, those who suffer from the effect of trauma cannot participate effectively in their new social environment.

\section{Legal Status Upon Arrival}

Landed claimants do not have permanent residential status when they come to Canada initially as claimants. Canada's Immigration Act has no category for individuals seeking refugee status from within; the Immigration Act's rules of admission distinguish only two classes of people: immigrants and visitors. Landed claimants acquire legal residential status only after they have successfully completed an inCanada refugee determination process.

Due to their insecure future, claimants lead a precarious life, at least until they acquire permanent residential status. This was more so in the 1980 s when the magnitude of inland refugee applications led to a huge backlog of refugee cases. Toward the end of 1989 , the backlog totalled over 121,000 cases (Adelman 1991). Although the introduction of Bill C55 in 1989 sped up the processing of existing claims, the influx of inland refugee applications continued to be large; approximately 36,000 per year. As a consequence, even with expanded state resources, a new backlog of unprocessed claimants emerged (Simmons, op cit.).

After successfully completing the refugee determination process, claimants could wait as long as 24 months before receiving permanent status (Employment and Immigration Canada). Findings from a study of Ghanaian claimants who came to Canada between 1985 and 1986 found that the overwhelming majority waited three years and more before residential status was conferred (Opoku-Dapaah 1993).

The refugee backlog can prolong the duration of the inland refugee application period and its attendant anxieties. The inland refugee determination process which claimants undergo before acquiring legal residential status in Canada can therefore have a negative psychological impact. The EIC Advisory Council (1985) indicated that the slowness of the inland determination process places a psychological burden on the claimant which can be even more damaging than the material hardships he or she suffers.

\section{Linguistic/Educational/ Occupational Preparedness}

Canada's official immigration policy requires potential immigrants and refugees to undergo screening and selection processes abroad before admission is granted. Since claimants do not go through the established screening and selection processes prior to their arrival, Canadian authorities cannot determine whether claimants possess sufficient levels of linguistic, educational and occupational preparedness essential for integration into Canadian society.

Immigration regulations introduced in 1967 and reinforced in 1976 instituted a nondiscriminatory, but selective immigrant intake system based on a point scheme that favoured educational attainments, occupational skills, and financial resources, while minimizing personal biases of those officials responsible for admissions (Simmons 1990.). Potential immigrants and sponsored refugees therefore undergo a screening and selection process which emphasizes linguistic ability, formal education and occupational background-criteria deemed to be crucial to their integration into Canadian society. Given that Canada's official languages, educational standards and industrial work system differ from those of Third World countries, it is likely that a great portion of landed claimants will not have the acceptable levels of preparedness essential for integration into Canadian society.

\section{Settlement Assistance}

Landed claimants are eligible for most of the existing newcomers settlement assistance programs. However, these claimants are not eligible for the same assistance programs when they wait in the refugee backlog. Similarly, landed claimants are eligible for the Adjustment Assistance Program (AAP) that provides indigent newcomers with temporary financial support for up to a year, or until they are reasonably selfsufficient whichever comes first (Shane 1991). Claimants on the other hand, are ineligible for AAP, yet they qualify for a subsistence allowance which covers food, rent and other basics. Claimants therefore do not benefit from bridging programs, such as employment counselling and loan schemes, that are components of the AAP-reception and orientation programs that are meant to familiarize newcomers with their new sociocultural environment. This delay can affect their ability to understand Canadian society especially in the early stages of their settlement.

\section{Rights to Employment}

Landed claimants hold rights to participate in economic activities in Canada. For example, they are eligible 
for employment-related training. Claimants, on the other hand, require authorization before they can work and are ineligible for employment-related training. Prior to 1989, claimants were not permitted to work. Following the amendment of existing immigration regulations in 1989, they were given the right to work after they had successfully completed the first phase of the refugee hearing process or the case had been referred for full hearing (CEIC 1989). The amendment also allowed claimants, with no employment authorization, to work provided they arrived in Canada after May 21, 1986, or were in Canada prior to January 1 , 1989 (ibid, 2). [The new Minister of Citizenship and Immigration has recently introduced regulatory changes to enable refugee claimants to seek employment as soon as they are allowed into the determination process. - Ed.]

In addition, claimants are ineligible for employment-related programs such as the Canadian Jobs Strategy Program which is meant for upgrading skills, job development and retraining. Since claimants have neither access to employment related training, nor permission to engage in economic activities until authorized to do so, they are initially prevented from participating in economic activities in Canada. In some circumstances, joblessness can have its own psychological effects, for example, long term dependence on public assistance.

\section{Rights to Education}

Similar to other permanent residents of Canada, landed claimants have rights to participate in educational programs. They are also eligible for funding toward furthering their formal education. Claimants on the other hand, require formal authorization from immigration officials before beginning educational programs. Prior to 1989 , inland refugee applicants could not engage in any educational programs. However, as of 1989 , they were permitted to study after completing their first refugee hearing. Given the claimants' uncertain future, however, these new rules offered little in- centive for furthering their education. Findings from a study of Ghanaian claimants in Toronto in 1992 showed that the uncertainty surrounding the outcome of their refugee claims exerted a negative influence on their willingness to embark on formal studies (Opoku-Dapaah, op cit.). Such disincentives may be even more pronounced in the case of claimants who were compelled to migrate in the midst of their academic programs.

\section{Political and Other Rights}

Landed claimants who hold permanent resident status in Canada, but who are not yet citizens, have no political rights. Political rights are linked to citizenship, thus creating a gap in social and political rights of migrants and long term residents (Tomasi 1981). In addition, landed claimants have to wait two or more years after obtaining permanent resident status before they can take part in national political activities.

\section{Integration of Landed Claimants in Canada}

Having outlined the circumstances of landed claimants in Canada, this section of the paper seeks to develop a framework for explaining the integration of landed claimants. Previous research and theory on integration can generally be classified into three broad schools: the assimilationist approach (Park and Burgess 1924; Eisenstadt 1954; Gordon 1964); the pluralistic approach (Goldlust and Richmond 1974); and the structuralist school (Portes and Borocz 1989). Each tradition provides arguments which are useful for interpreting cases of both slow and rapid integration. Each, moreover, is suggestive with respect to understanding certain aspects of the integration of landed claimants in Canadian society. However, none of these major schools cover the full range of issues necessary to analyze the claimant's case. This is because they all focus on immigrants rather than refugees. In this manner they do not provide sufficient attention to the unique features of the refugee experience-namely, refugees are less likely to have planned their move; they often have fewer kin and community contacts in the receiving nation to buffer their arrival; and their move is associated with social crisis and personal trauma.

A small, emerging body of research has begun to focus specifically on the case of refugees. This literature gives particular attention to trauma, and argues that special medical, social and psychiatric services are necessary for assuring the recovery and integration of refugees (Kunz 1981; Portes and Borocz 1990). However, even this body of literature has given only superficial attention to the plight of refugee claimants. Claimants not only experience all the stress and disorienting experiences of regular refugees, but they also arrive in Canada not knowing if they can stay. Coming from the Third World and not having planned their move, their language and occupational skills may be particularly weak for integration into Canadian society. In addition, they may be unprepared for dealing with rejection and racism.

An explanatory framework focusing on the experiences and particular challenges faced by refugee claimants from Third World nations is offered in Figure 1. This framework builds on the existing literature, but goes beyond earlier work to specify new elements which need to be incorporated in order to interpret the case of Third World claimants. It indicates that the experiences of claimants in Canada-including their traumatized departure, delays in the acquisition of legal status, other administrative restrictions and ineligibility for settlement-related services-slow their integration. This is because the period during which they are a claimant involves anxiety; discouragement and economic dependency. The legacy of the claimant period then slows progress through other stages of settlement and integration. This can lead to their marginalization within the Canadian socioeconomic context. Ultimately, landed claimants will have to break away from the cycle of anxiety, depression and dependency before 
they can participate effectively in mainstream social and economic activities.

The explanatory framework is based on three phases derived from the experiences of Third World origin landed claimants, namely: claimant, settlement and integration phases. The essential characteristics of these phases and the elements outlined in Figure 1 are explained below.

The model begins with the first step in the flight process, pre-resettlement characteristics. This comprises the extrinsic and intrinsic aspects which the claimants bring to their new home. This has two major components: flightrelated factors and background characteristics of the refugees.

Flight-related factors refer to the repression, persecution and other human rights infractions which led to the departure of claimants. Without medical intervention and appropriate resettlement conditions, those traumatized by their flight to Canada cannot participate effectively in their new social environment, nor integrate into Canadian society.

Background characteristics consist of pre-migration variables likely to influence the integration process in the host environment. Background characteristics fall into two major categories: demographic and socioeconomic attributes. Demographic characteristics important to the integration process include: age on arrival, gender, marital status, and size of family. So-

\section{Figure 1: Integration of Landed Claimants in Canada An Explanatory Model}

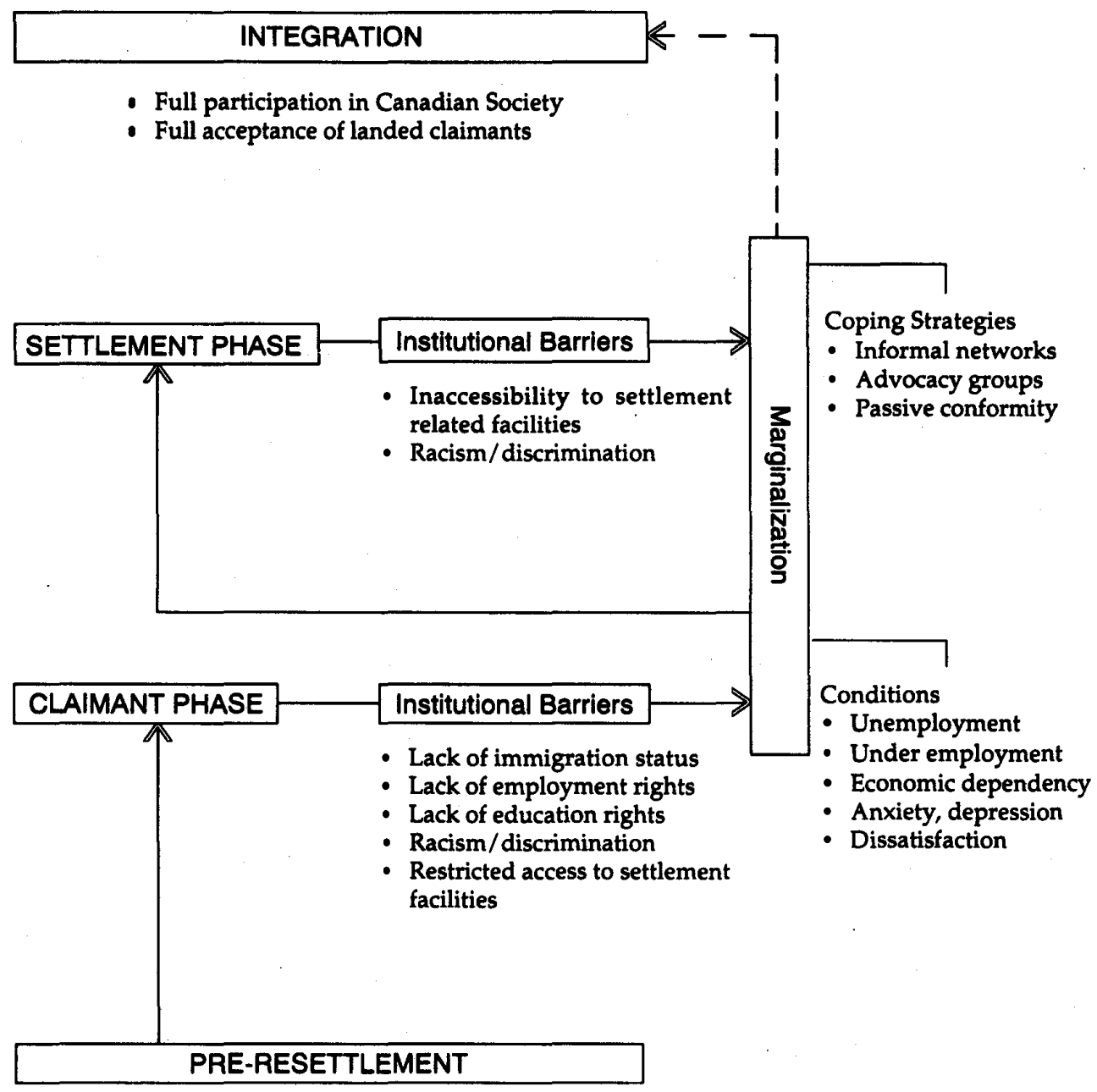

Flight Related Factors

- Root causes of displacement

- Trauma
Background Characteristics

- Demographic factors

- Sociocultural, economic and economic aspects ciocultural and economic characteristics include: occupational and educational background, marital status and language ability. The degree of occupational, linguistic and academic preparation of claimants will determine the extent to which they can participate in prevailing activities. Most claimants will require orientation, language training and skills retraining/ upgrading in order to enhance participation in mainstream activities.

\section{Claimant Phase}

This phase begins with the arrival of claimants in Canada seeking refugee status and ends with the completion of the refugee determination process. In the 1980 s, the claimant phase could last two years or more, depending on the

Refuge, Vol. 13, No. 9 (February 1994) 
refugee determination process and the refugee backlog. Claimants encounter administrative rules and restrictions which govern their social and economic activities in Canada. As shown in Figure 1, the claimant phase is associated with "institutional barriers" and "marginalization" of claimants.

Institutional barriers refer to the plethora of administrative regulations and the eligibility criteria which claimants confront. First, claimants have no definite immigration status. Delays in the acquisition of permanent resident status place claimants in limbo, creating uncertainties about the outcome of their application.

Second, in this phase claimants are denied employment and educational rights until they have appeared for their first level hearing. Furthermore, they cannot freely access settlement related services such as language training and skills training / upgrading programs. As a result, claimants become "marginalized." That is a situation whereby claimants are sidelined onto the periphery of mainstream Canadian society without participating fully in the social, economic and political institutions.

Claimants portray three employment characteristics: those without employment rights due to the lack of work authorization; those with work authorization but unable to find work (the majority of such claimants have to depend on public assistance for their subsistence); and those with employment authorizations who are compelled to work in "ghettoized" occupations. The condition of claimants can range from alienation to loss of identity. The relations which emerge between claimants and the host society do not permit them to live either according to their own standards nor to attain those of the host society (Kuhlman 1991, 49).

Claimants may adopt several coping mechanisms to deal with their circumstances. They may be drawn into networks of primary relationships with kin and compatriots. Claimants may set up community agencies or join existing ones to advocate for change.
Some passively accept the prevailing Canadian values without any in-depth commitment to them. Finally, those without working rights may engage in informal activities such as working unofficially. For a great number of the claimants, this state of marginalization can be filled with great dissatisfaction and anxiety. The institutional barriers, stereotyping by the media, deportation of compatriots and other disadvantages can foster reactive solidarity, that is, the growth of unity among groups whose members experience shared liabilities, disadvantages and discrimination (Gold 1992).

In summary, during the claimant phase, refugees encounter conditions which place them in insecure and marginalized socioeconomic circumstances. Those who become landed will have to overcome such circumstances in the settlement phase in order to integrate into Canadian society.

\section{Settlement Phase}

This phase begins with the formal acceptance of claimants as Convention Refugees; claimants become "landed." Landed claimants require information on the operation of Canadian institutions such as education, professional certification, upgrading, banking and religious systems.

Although the completion of the inland refugee determination process brings relief, realistically it does not end the disadvantageous conditions of refugees. Despite the fact that landed claimants are entitled to participate in and benefit from existing socioeconomic programs and facilities in the settlement phase, prevailing factors often prevent this. As shown in Figure 1 , the settlement phase is associated with institutional barriers which prevent access to settlement-related facilities, and lead to unemployment, underemployment and racism. Landed claimants may also encounter unemployment/underemployment due to non-recognition of prior occupational experience and academic attainments. In the case of those without any readily employable skills, lack of retraining and Canadian experience can hamper their job prospects. Landed claimants are compelled to take low-level jobs associated with poor wages, layoffs, and few options for advancement.

Landed claimants also encounter diverse forms of prejudice and ethnic discrimination. Racism can limit landed claimants' access to socioeconomic opportunities-especially in hiring and promotion contexts, housing policies, and in the provision of services.

Landed claimants are eligible for settlement-related programs and facilities, yet access is impeded by structural factors. Those who intend to pursue their education cannot access government funding and grants. Most Canadian provinces require landed claimants to work at least one year before qualifying for grants and governmental funding (Refuge Survey 1982). Access by newcomers to retraining in Ontario's public educational system, as well as in federal and provincially funded programs, is impeded by institutional barriers such as lack of publicity, entrance requirements, tuition fees, prerequisites, and full-time attendance requirements (Cummings 1989). Some training programs require stringent prerequisites such as work experience in Ontario or Canada, and language proficiency standards which immigrants find hard to meet.

The settlement phase can witness the participation of landed claimants in informal economic activities such as the peddling of merchandise in their ethnic community, and other small scale economic operations.

The cumulative effects of inaccessibility to facilities, lack of upgrading and retraining, underemployment and racism can lead to the marginalization of landed claimants. Thus, after the anxiety over the refugee claim has receded, further barriers in the socioeconomic arena arise to impede the integration of landed claimants.

\section{Integration Phase}

The integration phase is the final phase in the settlement process of refugees and immigrants to Canada. Landed 
claimants encounter a series of barriers and general inaccessibility to settlement related facilities which can create an expansive gap between the settlement and integration phases. As a consequence, in the settlement phase, landed claimants can fall into deplorable socioeconomic conditions. It is only when such Canadian residents overcome their marginalized conditions that they can proceed to the integration phase. In Figure 1, the broken arrows linking the marginalized condition to the integration phase depicts the precarious advance to the integration phase.

The integration of landed claimants may depend on two major factors. The first is the claimant's ability to advance from his/her low socioeconomic position-in itself made precarious by the depth of social deprivations and the length of time spent in marginalized circumstances.

The second factor is related to changes in the receiving society, not only through the provision of a favourable settlement context, but also by sociocultural adjustments within the wider society which facilitate the acceptance and civic participation of landed claimants.

\section{Conclusion}

The preceding framework is useful for the study of the settlement pattern of landed claimants for two reasons. First, it enables us to explain the effect that the inland refugee determination process has on the settlement process of landed claimants. Second, it enables us to show the impact of cultural factors such as racism, and structural factors such as access to socioeconomic facilities, on the settlement process of Third World origin claimants.

\section{References}

Adelman, H. 1991. "Postwar Development of Canada's Refugee Policy." in Refugee Policy: Canada and the United States, edited by Howard Adelman, 172-223. Toronto: York lanes Press.

Boyd, M. 1987. Migrant Women in Canada: Profiles and Policies. Ottawa: OECD.
Cummings, P. et al. 1989. Access/ Task Force on Access to Professions and Trades in Ontario. Toronto: Ontario Ministry of Citizenship.

Eisenstadt. 1954. The Absorption of Immigrants. London: Routledge \& Kegan Paul.

Employment and Immigration Canada. 1992. Managing Immigration: A Framework for the 90s. Ottawa.

1989. Background on Process Allowing Back$\log$ Claimants to Work. Ottawa.

Gold, J.S. 1992. Refugee Communities: A Comparative Field Study. London: Ságe Publications.

Gordon, M. 1964. Assimilation in American Life. New York: Oxford University Press

Kuhlman, T. 1991. "The Integration of Refugees in Developing Countries." In Journal of Refugee Studies 4(?).

Kunz, E. 1981. "Exile and Resettlement: Refugee Theory." In International Migration Review 15(1/2):42-51.

Opoku-Dapaah, E. 1993. Adaptation of Ghanaian Refugees in Toronto. Toronto: York Lanes Press.

Park, R.E. and Burgess, E.W. 1924. Introduction to the Science of Sociology. Chicago: The University of Chicago Press.

Portes, A. and Borocz, J. 1990. “Contemporary Immigration: Determinants and Modes of Incorporation." In International Migration Review 23:606-30.

Richmond, A.H. 1989. The Context of Refugee Resettlement: Refugees and Racism in Canada. YorkUniversity: Centre for Refugee Studies.

Rumbaut, R.G. 1991. "Migration, Adaptation, and Mental Health: The Experience of Southeast Asian Refugees in the United States." In Adelman, H. (ed.) Refugee Policy: Canada and the United States. Toronto: York Lanes Press.

Satzewich, V. 1991. "Capital Accumulation and State Formation: The Contradictions of International Migration." In Bolaria, S.B. (ed.) Social Issues and Contradictions in $\mathrm{Ca}$ nadian Society. Toronto: H.B.J. Ltd.

Shane, R. 1991. Evaluation of The Adjustment Assistance Program. Ottawa: EIC.

Simmons, A.B. 1990. Third World Immigration to Canada: New Challenges and Opportunities for Addressing a Common Global Future. Ottawa: IDRC.

Stoffman, D. 1992. "The High Costs of Our Refugee System." In The Toronto Star, Sept. 20.

Tomasi, S. 1981. "Sociopolitical Participation of Migrants in the Receiving Countries." In Kritz, M. et al. (eds.) Global Trends in Migration. New York: Centre for Migration Studies.

U.S. Committee for Refugees. 1982. World Refuge Survey. Washington.

Verma, B.P. and Bun Kwok, C. 1992. Asian Immigration to Canada: A Study in Socioeconomic Adaptation and Performance. Ottawa: Statistics Canada. $\square$

\section{NOW AVAILABLE}

Broling Gromid:

The 1956 Inngerian

remgee Wor want

36 Chito

thes

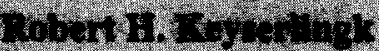

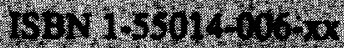

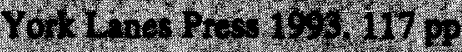

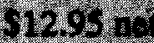

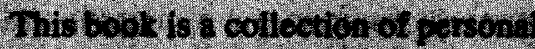

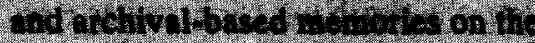

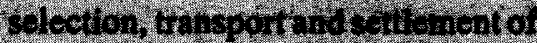

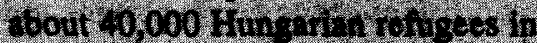

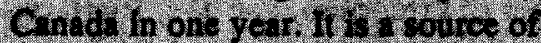

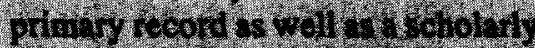

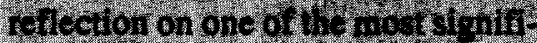

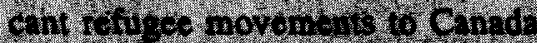

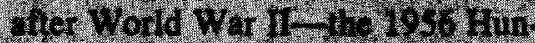

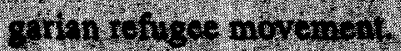

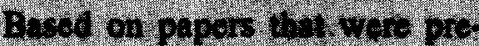

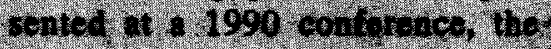

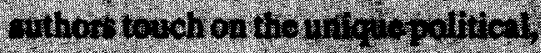

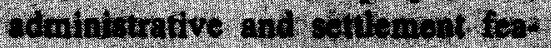

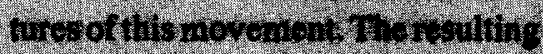

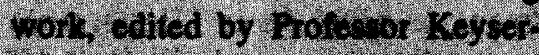

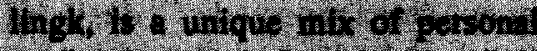

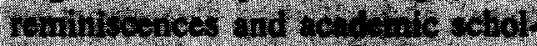

+1,

Ponthor

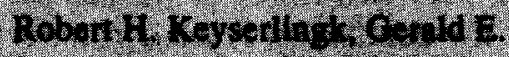

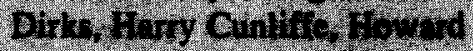

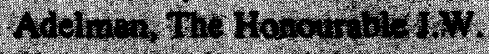

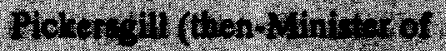

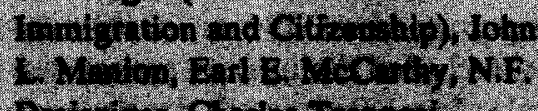

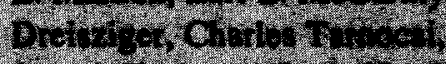

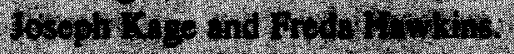

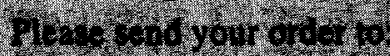

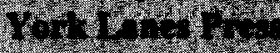

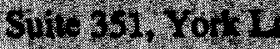

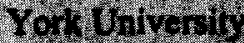

$400 \times 1,312$

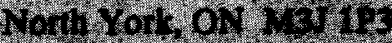

1..13

TIE $(4,6) 7,4.96$

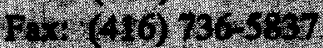

